\title{
Effect of Recombinant Stem Cell Factor on Clonogenic Maturation and Cycle Status of Human Fetal Hematopoietic Progenitors
}

\author{
KURT R. SCHIBLER, ROBIN K. OHLS, TRONG LE, KENNETH W. LIECHTY, AND \\ ROBERT D. CHRISTENSEN
}

Division of Human Development and Aging, Division of Neonatology, and the Clinical Research Center, University of Utah School of Medicine, Salt Lake City, Utah 84132

\begin{abstract}
Studies were undertaken to delineate the actions of stem cell factor (SCF) on human fetal hematopoietic progenitors in vitro. Mononuclear cells from umbilical cord blood of term fetuses were "panned" immunologically, and the resulting hematopoietic progenitors were grown in methylcellulose culture containing various concentrations of SCF alone or in combination with other recombinant hematopoietic growth factors. Neutralizing antibodies to IL-3 and granulocyte-macrophage colonystimulating factor were added to all plates to which recombinant IL-3 or granulocyte-macrophage colony-stimulating factor were not included to decrease any confounding effect resulting from production of small quantities of these factors within the culture plates. SCF, as a single agent, supported clonogenic maturation of fetal granulocyte-macrophage progenitors (granulocyte-macrophage colonyforming unit, $p<0.05$ ), multipotent progenitors (CFUMIX, $p<0.05$ ), and erythroid progenitors (erythroid burstforming unit, $p<0.05$ ). When combined with subplateau concentrations $(0.1 \mu \mathrm{g} / \mathrm{L})$ of IL-3 or granulocyte-macrophage colony-stimulating factor, SCF had an additive or synergistic effect on clonogenic maturation of granulocytemacrophage colony-forming unit and CFU-MIX. When combined with higher concentrations $(5.0 \mu \mathrm{g} / \mathrm{L})$ of IL-3 or granulocyte-macrophage colony-stimulating factor, SCF generally did not enhance colony formation but did increase the number of cells per colony. Like other pleiotropic cytokines such as IL-6, IL-9, and IL-11, SCF had a broad spectrum of action of fetal hematopoietic progenitors. (Pediatr Res 35: 303-306, 1994)
\end{abstract}

\section{Abbreviations}

MEM, modified minimal essential medium

SCF, stem cell factor

GM-CSF, granulocyte-macrophage colony-stimulating factor

G-CSF, granulocyte colony-stimulating factor

CFU-GM, granulocyte-macrophage colony-forming unit CFU-MIX, multipotent colony-forming unit

BFU-E, erythroid burst-forming unit

Received May 14, 1993; accepted October 26, 1993

Correspondence: Kurt R. Schibler, M.D., Division of Human Development and Aging, University of Utah School of Medicine, 50 North Medical Drive, Salt Lake City, UT 84132

Supported by Grants HL-44951, HD-00988, RR-00064, and HD01006 from the National Institutes of Health and by a grant from the Primary Children's Medical Center Foundation.
$\mathrm{SCF}$, a glycoprotein growth factor, is the ligand for the tyrosine kinase receptor encoded by c-kit (1). In the presence of other hematopoietic growth factors, but not when used singly, SCF supports clonogenic maturation of hematopoietic progenitors obtained from the marrow of adult subjects (1-4). Murine studies indicate that SCF is expressed during the embryonic period and that, unlike GM-CSF and IL-3, SCF might play a role in early fetal hematopoietic differentiation and development $(5,6)$. The effect of SCF on human fetal hematopoietic progenitors, however, has not been reported. We hypothesized that SCF, in a manner similar to the cytokines IL-6 (7), IL-9 (8), and IL-I 1 (9), might have a broader spectrum of action on fetal than on adult hematopoietic progenitors. Specifically, we sought to determine whether SCF as a single agent might induce clonogenic maturation of fetal progenitors and whether it would act synergistically with other factors, such as IL-3 and GM-CSF.

\section{MATERIALS AND METHODS}

Subjects. Fetal blood was obtained by puncture of the umbilical vein at the placental end of the umbilical cord immediately after elective term cesarean section deliveries without labor. The studies were performed in accordance with protocols approved by the University of Utah Institutional Review Board.

Recombinant hematopoietic growth factors. Purified recombinant IL-3, G-CSF, and GM-CSF (R\&D Systems, Minneapolis, MN) were produced in Escherichia coli and purified to homogeneity, $95 \%$ or greater purity as determined by SDS-PAGE. Purified recombinant human erythropoietin (provided by Chugai-Upjohn Inc., Rosemont, IL) had a specific activity of more than $3 \times 10^{5} \mathrm{IU} / \mathrm{mg}$ with a purity of more than $99.7 \%$ by SDSPAGE. SCF (provided by Krisztina Zsebo, Amgen Inc., Thousand Oaks, CA) was produced by COS-1 cells transfected with SCF cDNA as previously described (3).

Antihuman IL-3 and antihuman GM-CSF antibodies were raised in goats immunized with purified recombinant human IL3 and GM-CSF (R\&D Systems). At a concentration of $10 \mathrm{mg} /$ L, anti-IL-3 neutralized approximately $80 \%$ of the biologic activity of $1.25 \mu \mathrm{g} / \mathrm{L}$ of recombinant human IL-3, but did not cross-react with IL-1, IL-2, IL-4, IL-6, tumor necrosis factor, GM-CSF, or G-CSF as determined by Western blot or ELISA. Anti-GM-CSF neutralized more than $90 \%$ of the biologic activity of $0.5 \mu \mathrm{g} / \mathrm{L}$ of recombinant human GM-CSF. No crossreactivity with IL-1, IL-2, IL-3, IL-4, IL-6, tumor necrosis factor, or G-CSF was detected by Western blot or ELISA.

Clonogenic cultures. Light-density cells (sp gr < 1.077) obtained from umbilical cord blood by density gradient centrifugation over Ficoll-Hypaque were incubated for $90 \mathrm{~min}$ in plastic flasks at $37^{\circ} \mathrm{C}$, after which nonadherent cells were incubated for $20 \mathrm{~min}$ at room temperature with murine antihuman monocyte (Leu-M5, Becton Dickinson, Mountain View, CA), anti-T lym- 
phocyte (Leu-1 and Leu-5b, Becton Dickinson), and antiglycophorin antibody (provided by Dr. Richard Langlois, Lawrence Livermore Laboratories, Livermore, CA). Cells to which IgG had attached were removed by incubation in plates coated with goat antimouse $\operatorname{IgG}$ (Zymed, San Francisco, CA) for $70 \mathrm{~min}$ at $4^{\circ} \mathrm{C}$. Cells remaining in solution were plated in quadruplicate at a density of $2 \times 10^{6}$ cells $/ \mathrm{L}$, in $1-\mathrm{mL}$ culture plates containing $\alpha$ MEM (Hyclone, Logan, UT), $5 \times 10^{-4} \mathrm{~mol} / \mathrm{L} \beta$-mercaptoethanol (Eastman Chemical Co., Rochester, NY), 30\% FCS (Hyclone), $1 \%$ BSA (Sigma Chemical Co., St. Louis, MO), and $1.1 \%$ methylcellulose (Sigma). Cultures were maintained at $37^{\circ} \mathrm{C}$ and $5 \%$ $\mathrm{CO}_{2}$.

Cells were cultured in the presence of various concentrations of SCF $(0,0.5,5$, or $50 \mu \mathrm{g} / \mathrm{L})$, either alone or in combination with IL-3 $(0.1$ or $5.0 \mu \mathrm{g} / \mathrm{L})$, or GM-CSF $(0.1$ or $5.0 \mu \mathrm{g} / \mathrm{L})$, or the combination of IL-3 plus GM-CSF (each at $0.1 \mu \mathrm{g} / \mathrm{L}$ or at 5.0 $\mu \mathrm{g} / \mathrm{L}$ ). Plates to which IL-3 was not added received $30 \mathrm{mg} / \mathrm{L}$ anti-IL-3 neutralizing antibody. Similarly, plates to which no GM-CSF was added received anti-GM-CSF neutralizing antibody $(30 \mathrm{mg} / \mathrm{L})$. (Neutralizing antibodies at these concentrations decrease colony formation of fetal progenitors cultured in the absence of growth factors by greater than $90 \%$.) Erythropoietin $(2000 \mathrm{IU} / \mathrm{L})$ was added to all plates after $72 \mathrm{~h}$. After $14 \mathrm{~d}$, colonies were categorized in situ as CFU-GM colonies if no red cell elements were present and the colonies were composed of more than 50 cells, as CFU-MIX colonies if they contained red tightly clustered elements plus loosely arranged cells, and as BFU-E colonies if they were composed of red tightly clustered, multicentered aggregates.

Immunophenotype analysis. The proportion of purified cord blood light-density cells expressing the CD34 antigen was determined by fluorescence-activated cell sorter analysis (FACStar flow cytometer, Becton Dickinson). Cells were stained by incubation in the dark for $45 \mathrm{~min}$ at $4^{\circ} \mathrm{C}$ with phycoerythrin-conjugated anti-CD34 antibody (Becton Dickinson). Expression of surface CD34 antigen was detected on $4.3 \%$ in the purified cell population. Expression of the monocyte marker, Leu-M3-FITC (Becton Dickinson), was observed on $0.6 \%$ of cells expressing the CD34 antigen.

Tritiated thymidine suicide studies. Fetal light-density cells were incubated at $37^{\circ} \mathrm{C}$ and $5 \% \mathrm{CO}_{2}$, under serum-free conditions, for $3.5 \mathrm{~h}$ in either $\alpha$-MEM alone or in $\alpha$-MEM with SCF $(0.5,5$, or $50 \mu \mathrm{g} / \mathrm{L})$. Tritiated thymidine suicide studies were then performed according to the methods of $\mathrm{Lu}$ et al. (10). Briefly, after the incubations, each aliquot was split into three tubes. Tritiated thymidine of high specific activity $(86 \mathrm{Ci} / \mathrm{mmol}$, Amersham, Arlington Heights, IL) was added to one tube, nontritiated cold thymidine ( $500 \mu \mathrm{g}$, Sigma) was added to a second tube, and tritiated thymidine plus cold thymidine was added to a third tube for an additional 20 -min incubation, with agitation every $5 \mathrm{~min}$. Cells were then washed twice with cold thymidine wash buffer $(100 \mathrm{mg} / \mathrm{L})$ and plated in clonogenic cultures in the presence of IL-3 $(1 \mu \mathrm{g} / \mathrm{L})$, GM-CSF $(1 \mu \mathrm{g} / \mathrm{L})$, and G-CSF $(1 \mu \mathrm{g} /$ L). Erythropoietin $(2000 \mathrm{IU} / \mathrm{L})$ was added to all cultures after $72 \mathrm{~h}$.

Data analysis. Statistical comparisons were performed using the two-tailed $t$ test.

\section{RESULTS}

The effect of SCF on clonogenic maturation of fetal CFU-GM is shown in Table 1. As a single agent, $\mathrm{SCF}(\geq 5 \mu \mathrm{g} / \mathrm{L})$ supported development of fetal CFU-GM colonies $(5 \pm 1$ CFU-GM colonies $/ 10^{4}$ plated cells in control plates versus $17 \pm 2$ colonies in plates to which SCF was added; $p<0.05$ ). The effect of SCF on CFU-GM formation was additive to that of a subplateau concentration $(0.1 \mu \mathrm{g} / \mathrm{L})$ of IL-3. SCF $(5 \mu \mathrm{g} / \mathrm{L})$ was also additive to a subplateau $(0.1 \mu \mathrm{g} / \mathrm{L})$ as well as a higher concentration $(5.0 \mu \mathrm{g} /$ $\mathrm{L}$ ) of GM-CSF and to the combination of IL-3 plus GM-CSF
Table 1. Effects of SCF alone or in combination with IL-3 and GM-CSF on colony formation by CFU-GM of fetal origin*

\begin{tabular}{lrrrc}
\hline & \multicolumn{4}{c}{ SCF $(\mu \mathrm{g} / \mathrm{L})$} \\
\cline { 2 - 5 } & \multicolumn{1}{c}{0} & 0.5 & \multicolumn{1}{c}{5} & 50 \\
\hline Control & $5 \pm 1$ & $8 \pm 1$ & $17 \pm 2 \dagger$ & $19 \pm 3 \dagger$ \\
IL-3 $(0.1 \mu \mathrm{g} / \mathrm{L})$ & $20 \pm 2$ & $18 \pm 2$ & $38 \pm 3 \dagger$ & $23 \pm 2$ \\
IL-3 $(5 \mu \mathrm{g} / \mathrm{L})$ & $26 \pm 4$ & $26 \pm 3$ & $34 \pm 4$ & $33 \pm 2$ \\
GM-CSF $(0.1 \mu \mathrm{g} / \mathrm{L})$ & $30 \pm 3$ & $31 \pm 2$ & $59 \pm 10 \dagger$ & $30 \pm 2$ \\
GM-CSF $(5 \mu \mathrm{g} / \mathrm{L})$ & $30 \pm 3$ & $32 \pm 3$ & $56 \pm 7 \dagger$ & $36 \pm 3$ \\
IL-3 + GM-CSF $(0.1 \mu \mathrm{g} / \mathrm{L})$ & $30 \pm 2$ & $33 \pm 4$ & $51 \pm 7 \dagger$ & $31 \pm 2$ \\
IL-3 + GM-CSF $(5 \mu \mathrm{g} / \mathrm{L})$ & $34 \pm 3$ & $32 \pm 2$ & $72 \pm 8 \dagger$ & $35 \pm 3$
\end{tabular}

* CFU-GM-derived colonies that developed in quadruplicate culture plates from three subjects. Two thousand light-density, nonadherent, Tlymphocyte, B-lymphocyte, and monocyte-depleted cells $/ \mathrm{mL}$ were cultured in the presence of various concentrations of SCF plus various concentrations of IL-3 and GM-CSF. Colonies were expressed as mean \pm SEM per 10000 plated cells.

$\dagger p<0.05$ vs no SCF.

Table 2. Effects of SCF alone or in combination with IL-3 and GM-CSF on colony formation by CFU-MIXX of fetal origin*

\begin{tabular}{lrrrr}
\hline & \multicolumn{4}{c}{$\mathrm{SCF}(\mu \mathrm{g} / \mathrm{L})$} \\
\cline { 2 - 5 } & \multicolumn{1}{c}{0} & \multicolumn{1}{c}{0.5} & \multicolumn{1}{c}{5} & \multicolumn{1}{c}{50} \\
\hline Control & $2 \pm 0$ & $4 \pm 1$ & $5 \pm 1 \dagger$ & $3 \pm 1$ \\
$\mathrm{IL}-3(0.1 \mu \mathrm{g} / \mathrm{L})$ & $20 \pm 3$ & $19 \pm 3$ & $30 \pm 3 \dagger$ & $10 \pm 1$ \\
$\mathrm{IL}-3(5 \mu \mathrm{g} / \mathrm{L})$ & $12 \pm 3$ & $15 \pm 4$ & $22 \pm 5$ & $10 \pm 1$ \\
GM-CSF $(0.1 \mu \mathrm{g} / \mathrm{L})$ & $14 \pm 3$ & $13 \pm 2$ & $23 \pm 2 \dagger$ & $9 \pm 2$ \\
GM-CSF $(5 \mu \mathrm{g} / \mathrm{L})$ & $12 \pm 2$ & $11 \pm 3$ & $13 \pm 1$ & $8 \pm 2$ \\
$\mathrm{IL}-3+\mathrm{GM}-\mathrm{CSF}(0.1 \mu \mathrm{g} / \mathrm{L})$ & $17 \pm 3$ & $21 \pm 4$ & $33 \pm 3 \dagger$ & $12 \pm 1$ \\
IL-3 $+\mathrm{GM}-\mathrm{CSF}(5 \mu \mathrm{g} / \mathrm{L})$ & $17 \pm 3$ & $13 \pm 4$ & $20 \pm 3$ & $12 \pm 2$ \\
\hline
\end{tabular}

* CFU-MIX-derived colonies that developed in quadruplicate culture plates from three subjects. Two thousand light-density, nonadherent, Tlymphocyte, B-lymphocyte, and monocyte-depleted cells/mL were cultured in the presence of various concentrations of SCF plus various concentrations of IL-3 and GM-CSF. Colonies were expressed as mean \pm SEM per 10000 plated cells.

$\dagger p<0.05$ vs no SCF.

Table 3. Effects of SCF alone or in combination with $I L-3$ and GM-CSF on colony formation by BFU-E of fetal origin*

\begin{tabular}{lrrrc}
\hline & \multicolumn{4}{c}{ SCF $(\mu \mathrm{g} / \mathrm{L})$} \\
\cline { 2 - 5 } & \multicolumn{1}{c}{0} & \multicolumn{1}{c}{0.5} & \multicolumn{1}{c}{5} & \multicolumn{1}{c}{50} \\
\hline Control & $4 \pm 1$ & $5 \pm 1$ & $8 \pm 1 \dagger$ & $9 \pm 2 \dagger$ \\
IL-3 $(0.1 \mu \mathrm{g} / \mathrm{L})$ & $20 \pm 2$ & $18 \pm 3$ & $19 \pm 3$ & $19 \pm 4$ \\
IL-3 $(5 \mu \mathrm{g} / \mathrm{L})$ & $23 \pm 2$ & $24 \pm 6$ & $24 \pm 4$ & $29 \pm 2$ \\
GM-CSF $(0.1 \mu \mathrm{g} / \mathrm{L})$ & $15 \pm 2$ & $15 \pm 3$ & $22 \pm 3$ & $15 \pm 3$ \\
GM-CSF $(5 \mu \mathrm{g} / \mathrm{L})$ & $11 \pm 2$ & $10 \pm 2$ & $14 \pm 2$ & $16 \pm 3$ \\
IL-3 + GM-CSF $(0.1 \mu \mathrm{g} / \mathrm{L})$ & $26 \pm 4$ & $24 \pm 3$ & $30 \pm 4$ & $22 \pm 3$ \\
IL-3 + GM-CSF $(5 \mu \mathrm{g} / \mathrm{L})$ & $24 \pm 4$ & $9 \pm 2$ & $23 \pm 4$ & $23 \pm 2$ \\
\hline
\end{tabular}

* BFU-E-derived colonies that developed in quadruplicate culture plates from three subjects. Two thousand light-density, nonadherent. Tlymphocyte, B-lymphocyte, and monocyte-depleted cells/mL were cultured in the presence of various concentrations of SCF plus various concentrations of IL-3 and GM-CSF. Colonies were expressed as mean \pm SEM per 10000 plated cells.

$\dagger p<0.05$ vs no SCF.

(whether at $0.1 \mu \mathrm{g} / \mathrm{L}$ each or at $5.0 \mu \mathrm{g} / \mathrm{L}$ each). This effect was not observed at higher concentrations of SCF $(50 \mu \mathrm{g} / \mathrm{L})$.

The effect of SCF on clonogenic maturation of fetal CFUMIX is shown in Table 2. As a single agent, SCF $(5 \mu \mathrm{g} / \mathrm{L})$ supported development of a small number of fetal CFU-MIX colonies $\left(2 \pm 0\right.$ colonies $/ 10^{4}$ plated cells in control plates versus $5 \pm 1$ colonies in plates to which SCF was added, $p<0.05$ ). The effect of SCF on the development of fetal CFU-MIX was additive 


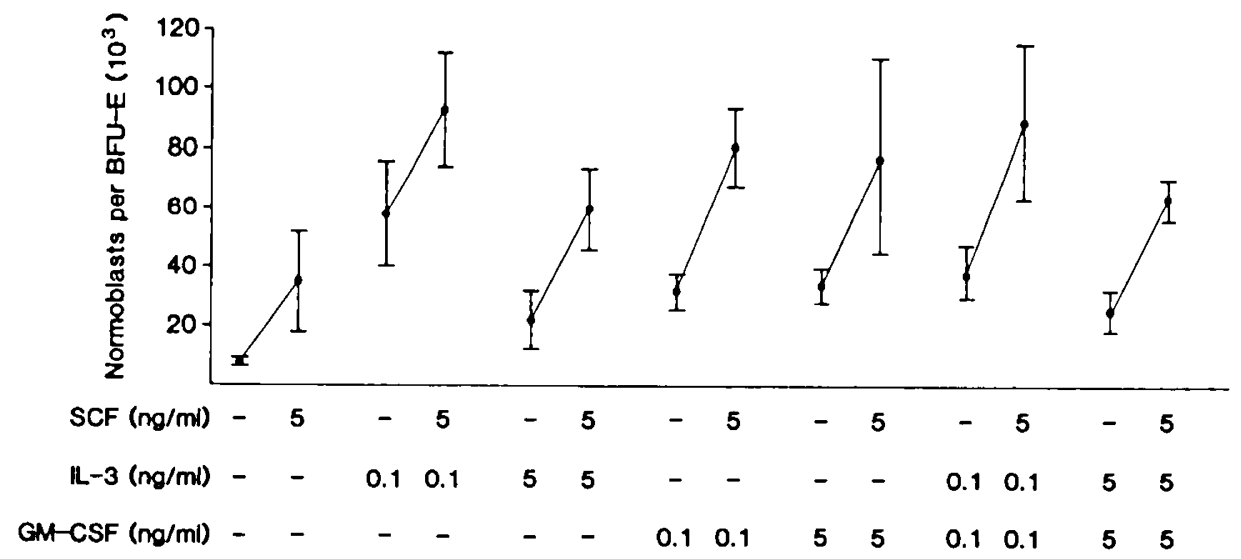

Fig. 1. Effect of SCF alone or in combination with IL-3 and/or GM-CSF on the number of normoblasts per BFU-E colony. BFU-E from three individuals (four BFU-E per experiment) were plucked, and normoblasts were counted on a hemocytometer. The numbers represent mean \pm SEM.

to that of a subplateau concentration $(0.1 \mu \mathrm{g} / \mathrm{L})$ of IL-3. The effect of SCF was not additive, however, to that of a higher concentration of IL-3 $(5 \mu \mathrm{g} / \mathrm{L})$. Similarly, the effect of SCF was additive to a submaximal concentration of GM-CSF $(0.1 \mu \mathrm{g} / \mathrm{L})$, and submaximal concentrations of IL-3 plus GM-CSF (each at $0.1 \mu \mathrm{g} / \mathrm{L}$ ). The effect of SCF was not additive to a higher concentration of GM-CSF $(5 \mu \mathrm{g} / \mathrm{L})$, or to the combination of IL-3 and GM-CSF (each at $5 \mu \mathrm{g} / \mathrm{L}$ ).

The effect of SCF on clonogenic maturation of fetal BFU-E is shown in Table 3. As a single agent, SCF $(\geq 5 \mu \mathrm{g} / \mathrm{L})$ supported development of fetal BFU-E; however, no additive effect on the number of BFU-E colonies formed was observed when SCF was added to IL-3, GM-CSF, or to combinations of IL-3 plus GMCSF. Despite the lack of increase in BFU-E colony number, the size of the individual BFU-E colonies increased when grown in the presence of SCF (Fig. 1).

Incubation of fetal progenitors for $4 \mathrm{~h}$ with SCF in concentrations of 0.5 to $50 \mu \mathrm{g} / \mathrm{L}$ did not result in an increase in the proportion of progenitors killed by tritiated thymidine of high specific activity. Thus, the proliferative action of SCF on fetal progenitors does not appear to be the result of the direct action of SCF on cell cycle status of hematopoietic progenitors.

\section{DISCUSSION}

SCF appears to have a critical role in embryonic and fetal hematopoietic development. Schmitt et al. (5) observed that SCF and c-kit were among the factors expressed in undifferentiated embryonic murine stem cells, whereas GM-CSF and IL-3 were not. The importance of SCF and its interaction with the c-kit receptor during early development are illustrated by murine strains with mutations at the $\mathrm{W}$ locus encoding the c-kit product and mice with the mutation of the $\mathrm{S} 1$ locus encoding SCF protein $(1,11-13)$. Both strains exhibit pleotropic developmental defects not only in hematopoiesis but also in gametogenesis and melanogenesis $(6,11-13)$.

The precise role of SCF in human fetal hematopoietic development is not clear. The present studies indicate that progenitors of human fetal origin can be influenced by recombinant SCF and that, in a manner similar to IL-6, IL-9, and IL-1 1, SCF has a somewhat broader spectrum of action on fetal progenitors than that reported by other investigators on adult hematopoietic progenitors because adult progenitors do not develop clones when stimulated by SCF alone (7-9). Specifically, we observed that when used as a single agent, SCF supported clonogenic maturation of about $70 \%$ of the CFU-GM colonies that developed when stimulated with IL-3 and about $60 \%$ of the CFU-GM colonies that developed when stimulated with GM-CSF. This effect appears to be independent of in vitro expression of IL-3 and GMCSF by fetal progenitors in culture because neutralizing antibodies to IL-3 and GM-CSF were included in the culture media (14).
SCF exhibited synergistic effects with IL-3 and GM-CSF, resulting in not only an increase in the number of colonies but also in the quantity of cells per colony.

At the highest dose of SCF $(50 \mu \mathrm{g} / \mathrm{L})$ evaluated, a loss of synergism was observed with either IL-3 or GM-CSF with respect to maturation of CFU-GM and CFU-MIX colonies. One possible explanation for this phenomenon is that high SCF concentrations down-regulate its receptor, c-kit. This effect of high concentrations of SCF has been documented by two groups of investigators $(6,15)$. A second explanation is that with high ligand (SCF) concentration the efficiency of dimerization of $c$-kit receptor is diminished (6). Yet another possibility is that large quantities of soluble SCF might inhibit cell-cell interactions mediated through the membrane-bound form of SCF on one cell interacting with the receptor on an adjacent cell in culture $(16,17)$. This interaction, which appears to be important in maintenance of hematopoietic stem cells in long-term culture, might be inhibited by binding of excess soluble SCF to receptors or by downregulation of SCF receptors on adjacent cells.

Although the regulation of hematopoiesis during fetal development is poorly understood, this area of study is becoming relevant to clinicians as well as to scientists. An understanding of fetal hematopoietic control provides insight into the pathophysiologic mechanisms operative in prematurely delivered neonates. For instance, an important problem in neonatology practice involves the very high incidence of nosocomial infections in extremely preterm infants (18). The basis for this defective antibacterial defense appears to involve a relatively small neutrophil reserve per kilogram of body weight $(19,20)$, a significant limitation in up-regulating neutrophil production during bacterial infection (21), and relatively poor neutrophil adherence, chemotaxis, and superoxide generation (22-27). Effective and safe methods of improving neutrophil production and function in preterm neonates would be of interest as potential means of decreasing the incidence or severity of infections. With this in mind, Cairo et al. $(28,29)$ tested the administration of various hematopoietic growth factors and cytokines, alone and in combination, to newborn rats. Promising results from the combination of G-CSF and SCF included a significant increase in blood and marrow neutrophil populations, improved neutrophil function, and improved survival after bacterial challenge (29). On the basis of the animal studies and the present experiments with human cells, we suspect that SCF is an important hematopoietic regulator in the human fetus. Issues regarding its regulation and actions, and any potential as a therapeutic agent in perinatal medicine, remain to be determined.

\section{REFERENCES}

1. Zsebo KH, Williams DA, Geissler EN, Broudy VC, Martin FH, Atkins HL. Hsu R-Y. Birkett NC, Okino KH, Murdock DC, Jacobsen FW, Langley KE, Smith KA, Takeishi T, Cattanach BM, Galli SJ, Suggs SV 1990 Stem cell 
factor is encoded at the S1 locus and is the ligand for the c-kit tyrosine kinase receptor. Cell 63:213-224

2. Zsebo KM, Wypych J, McNiece IK, Lu HS, Smith KA, Karkare SB, Sachdev RK, Yuschenkoff VN, Birkett NC, Williams LR, Satyagal VN, Tung W, Bosselman RA, Mendiaz EA, Langley KE 1990 Identification, purification, and biological characterization of the hematopoietic stem cell factor from buffalo rat liver-conditioned medium. Cell 63:195-201

3. Martin FH, Suggs SV, Langley KE, Lu HS, Ting J, Okino KH, Morris F, Mcniece IK, Jacobsen FW, Mendiaz EA, Birkett NC, Smith KA, Johnson MJ, Parker VP, Flores JC, Patel AC, Fisher EF, Erjavec HO, Herrera CJ, Wypych J, Sachdev RK, Pope JA, Leslie I, Wen D, Lin C-H, Cupples RL, Zsebo KM 1990 Primary structure and functional expression of rat and human stem cell factor DNAs. Cell 63:203-211

4. McNiece IK, Langley KE, Zsebo KM 1991 Recombinant human stem cell factor synergizes with GM-CSF, G-CSF, IL-3, and Epo to stimulate human progenitor cells of the myeloid and erythroid lineages. Exp Hematol 19:226231

5. Schmitt RM, Bruyns E, Snodgrass HR 1991 Hematopoietic development of embryonic stem cells in vitro: cytokine and receptor gene expression. Genes Dev 5:728-740

6. Blume-Jensen P, Claesson-Welsh L, Siegbahn A, Zsebo KM, Westermark B, Heldin C-H 1991 Activation of the human c-kit product by ligand-induced dimerization mediates circular actin reorganization and chemotaxis. EMBO J 10:4121-4128

7. Gardner D, Liechty K, Christensen R 1990 Effects of interleukin-6 on fetal hematopoietic progenitors. Blood 75:2150-2155

8. Holbrook ST, Ohls RK, Schibler KR, Yang Y-C, Christensen RD 1991 Effects of interleukin-9 on clonogenic maturation and cell-cycle status of fetal and adult hematopoietic progenitors. Blood 77:2129-2134

9. Schibler KR, Yang Y-C, Christensen RD 1992 Effects of interleukin-11 on clonogenic maturation of fetal and adult hematopoietic progenitors. Blood 80:900-903

10. Lu L, Broxmeyer H, Meyers P, Moore M, Thaler H 1983 Association to cell cycle expression of IA-like antigenic determinants on normal human multipotential (CFU-GEMM) and erythroid (BFU-E) progenitor cells with regulation in vitro by acid isoferritins. Blood 61:250-256

11. Chabot B, Stephesson DA, Chapwen VM, Besmer P, Bernstein A 1988 The proto-oncogene c-kit encoding a transmembrane tyrosine kinase receptor maps to the mouse $W$ locus. Nature 335:88-89

12. Geissler EN, Ryan MA, Houseman DE 1988 The dominant-white spotting (w) locus of the mouse encodes the c-kit proto-oncogene. Cell 55:185-192

13. Geissler EN, Liao M, Brook JD, Martin FH, Zsebo KM, Houseman DE, Gall SJ 1991 Stem cell factor, a novel hematopoietic growth factor and ligand for c-kit tyrosine kinase receptor, maps on human chromosome 12 between 12q14.3 and 12qter. Somatic Cell Mol Genet 17:207-214

14. Schibler KR, Ohls RK, Li Y, Le T Liechty KW, Durham M, Nye N, Christensen RD 1993 A mechanism accounting for the unique growth factor require- ments of hematopoietic progenitors from umbilical cord blood. Pediatr Res 33:285A(abstr)

15. Lev S, Yarden Y, Givol D 1992 Dimerization and activation of the kit receptor by monovalent and bivalent binding of the stem cell factor. J Biol Chem 267:15970-15977

16. Lowry PA, Deacon D, Whitefield P, Mcrath HE, Quesenberry PJ 1992 Stem cell factor induction of in vitro murine hematopoietic colony formation by subliminal cytokine combinations: the role of anchor factors. Blood 80:663669

17. Toksoz D, Zsebo KM, Smith KA, Hu S, Brankow D, Suggs SV Martin FH, Williams DA 1992 Support of human hematopoiesis in long-term bone marrow cultures by murine stromal cells selectively expressing the membrane-bound and secreted forms of the human homolog of the steel gene product, stem cell factor. Proc Natl Acad Sci USA 89:7350-7354

18. Barker CJ, Melish ME Hall RT, Casto DT, Vasan U, Givner LB 1992 Intravenous immune globulin for the prevention of nosocomial infection in low-birth-weight neonates. N Engl J Med 327:213-219

19. Christensen RD, Rothstein G 1984 Pre- and postnatal development of granulocytic stem cells in the rat. Pediatr Res 18:599-602

20. Erdman SH, Christensen RD, Bradley PP, Rothstein G 1982 Supply and release of storage neutrophils. Biol Neonate 41:132-137

21. Christensen RD, Macfarlane JL, Taylor NL, Hill HR, Rothstein G 1982 Blood and marrow neutrophils during experimental group $B$ streptococcal infection: quantification of stem cell, proliferative, storage, and circulating pools. Pediatr Res 16:549-553

22. Krause PJ, Maderazo EG, Scroggs M 1982 Abnormalities of neutrophil adherence in newborns. Pediatrics 69:184-187

23. Miller ME 1971 Chemotactic function in the human neonate: humoral and cellular aspects. Pediatr Res 5:487-492

24. Sacchi F, Rondini G, Mingrat G, Stronati M, Gancia GP, Marseglia GL, Siccardi AG 1982 Different maturation of neutrophil chemotaxis in term and preterm newborn infants. J Pediatr 101:273-274

25. Wright WC Jr, Ank BJ, Herbert J, Stiehm ER 1975 Decreased bacteriocidal activity of leukocytes of stressed newborn infants. Pediatrics 56:579-584

26. Anderson DC, Pickering LK, Feigen RD 1974 Leukocyte function in normal and infected neonates. J Pediatr 85:420-425

27. Shigeoka AO, Santos JI, Hill HR 1979 Functional analysis of neutrophilic granulocytes from healthy, infected, and stressed neonates. J Pediatr 95:454460

28. Cairo M, Plunkett J, Mauss D, van de Ven C 1990 Seven-day administration of recombinant human granulocyte colony-stimulating factor to newborn rats: modulation of neonatal neutrophilia, myelopoiesis, and group B streptococcus sepsis. Blood 76:1788-1794

29. Cairo MS, Plunkett JM, Nguyen A, van de Ven C 1992 Effect of stem cell factor with and without granulocyte colony-stimulating factor on neonatal hematopoiesis: in vivo induction of newborn myelopoiesis and reduction of mortality during experimental group B streptococcal sepsis. Blood 80:96101 